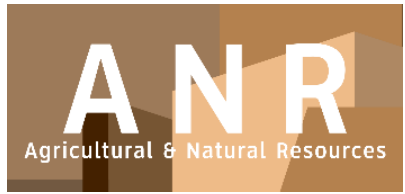

PAPER - OPEN ACCESS

\title{
Penerapan Instrumen Ekonomi Lingkungan Hidup dalam Kebijakan Pemberian Kredit Perbankan
}

\author{
Author \\ : Syapri Chan \\ DOI \\ : 10.32734/anr.v1i2.228 \\ Electronic ISSN \\ :2654-7023 \\ Print ISSN \\ : 2654-7015 \\ Volume 1 Issue 2 - 2018 TALENTA Conference Series: Agricultural \& Natural Resources (ANR)
}

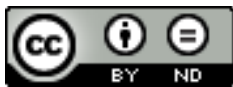

This work is licensed under a Creative Commons Attribution-NoDerivatives 4.0 International License.

Published under licence by TALENTA Publisher, Universitas Sumatera Utara
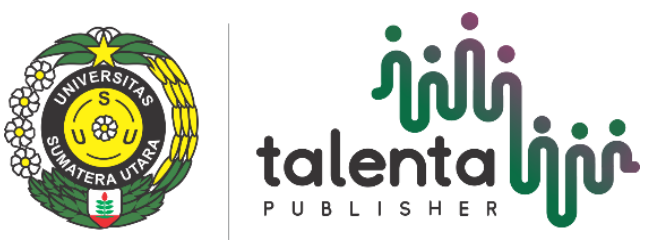


\title{
Penerapan Instrumen Ekonomi Lingkungan Hidup dalam Kebijakan Pemberian Kredit Perbankan
}

\author{
Syapri Chan ${ }^{\mathrm{a} *}$ \\ Fakultas Hukum, Universitas Al-Azhar Medan \\ syapri.lawyer@gmail.com
}

\begin{abstract}
Abstrak
Penerapan Instrumen Ekonomi Lingkungan Hidup dalam ketentuan Pasal 42 dan 43 Undang-Undang No. 32 Tahun 2009 tentang Perlindungan dan Pengelolaan Lingkungan Hidup dapat dilihat sebagai upaya mewujudkan pembangunan berkelanjutan yaitu memberikan perlindungan pada lingkungan hidup melalui pendekatan yang sejalan dengan kaidah-kaidah pasar ekonomi, sehingga upaya pengelolaan lingkungan hidup tidak mengganggu pertumbuhan sektor usaha dan ekonomi makro pada umumnya. Instrumen ekonomi lingkungan hidup (salah satunya adalah insentif dan/atau disinsentif) ini wajib dikembangkan dan diterapkan oleh Pemerintah dan pemerintah daerah dalam rangka melestarikan fungsi lingkungan hidup. Tujuan instrumen insentif dan/atau disinsentif ini adalah untuk melestarikan fungsi lingkungan hidup melalui pemberian kredit perbankan kepada nasabah debitur. Penelitianini dilakukan dengan metode penelitian hukum normatif dengan studi kepustakaan. Hasil dari penelitian ini adalah bahwa penerapan instrumen insentif dan/atau disinsentif ini sangat signifikan untuk mencegah terjadinya pencemaran dan perusakan lingkungan hidup karena sejak dari awal nasabah debitur yang mengajukan kredit/pembiayaan atas usaha dan/atau kegiatannya sudah dapat diketahui apakah nasabah debitur tersebut peduli atau lalai terhadap lingkungan hidup. Dengan penerapan instrumen insentif dan/atau disinsentif dalam pemberian kredit perbankan terhadap nasabah debitur maka dapat dipastikan pelestarian fungsi lingkungan hidup tetap terjaga dan kredit/pembiayaan yang diberikan perbankan kepada nasabah debitur tidak terjadi kredit macet.
\end{abstract}

Kata Kunci: Instrumen Ekonomi; Lingkungan Hidup; Pemberian Kredit; Hukum Perbankan

\section{Pendahuluan}

Dalam UU No. 32 Tahun 2009 tentang Perlindungan dan Pengelolaan Lingkungan Hidup, maka salah satu instrumen dalam upaya pencegahan pencemaran dan kerusakan lingkungan adalah instrumen ekonomi lingkungan hidup.Melalui instrumen ekonomi ini diharapkan adanya dorongan dan dukungan dari berbagai pihak untuk dapat mengimplementasikan UU tersebut. Melalui berbagai kebijakan serta program-program Kementerian LH dan Kehutanan yang telah dikembangkan maka diharapkan akan terjadi perubahan paradigma dalam melindungi dan mengelola lingkungan hidup kita. 
Upaya melindungi dan mengelola bukanlah untuk tujuan perlindungan fungsi lingkungan semata tetapi juga mampu memberikan peluang bagi penciptaan usaha kegiatan ekonomi baru, perluasan dan peningkatan kualitas tenaga kerja, serta pengembangan teknologi dan budaya ramah lingkungan.

Dalam hal penciptaan usaha kegiatan ekonomi baru yang lebih ramah lingkungan maka kegiatan ini haruslah diimbangi dengan pembentukan aturan dan kebijakan pembiayaan keuangan yang mempersyaratkan perlindungan dan pengelolaan lingkungan hidup pada sistem lembaga keuangan bank dan lembaga keuangan non-bank.

Berdasarkan UU No. 32 Tahun 2009 tentang Perlindungan dan Pengelolaan Lingkungan Hidup, ada diatur tentang Instrumen Ekonomi Lingkungan Hidup yang meliputi a. perencanaan pembangunan dan kegiatan ekonomi, b. pendanaan lingkungan hidup; dan c. insentif dan/atau disinsentif (Pasal 42 ayat (2) huruf c).

Insentif merupakan upaya memberikan dorongan atau daya tarik secara moneter dan/atau nonmoneter kepada setiap orang ataupun Pemerintah dan pemerintah daerah agar melakukan kegiatan yang berdampak positif pada cadangan sumber daya alam dan kualitas fungsi lingkungan hidup. Sedangkan disinsentif merupakan pengenaan beban atau ancaman secara moneter dan/atau nonmoneter kepada setiap orang ataupun Pemerintah dan pemerintah daerah agar mengurangi kegiatan yang berdampak negatif pada cadangan sumber daya alam dan kualitas fungsi lingkungan hidup (Penjelasan Pasal 42 ayat (2) huruf c).

Insentif dan/atau disinsentif antara lain diterapkan dalam bentuk pengembangan sistem lembaga keuangan yang ramah lingkungan hidup (Pasal 43 ayat (3) huruf c). Sistem lembaga keuangan ramah lingkungan hidup adalah sistem lembaga keuangan yang menerapkan persyaratan perlindungan dan pengelolaan lingkungan hidup dalam kebijakan pembiayaan dan praktik sistem lembaga keuangan bank dan lembaga keuangan nonbank (Penjelasan Pasal 43 ayat (3) huruf c).

Dalam mengaplikasikan Insentif dan Disinsentif melalui pemberian kredit Perbankan, maka pemanfaatannya dapat dilakukan melalui kegiatan, sebagai berikut [3]:

- Pajak Lingkungan

- Subsidi

Subsidi dapat berbentuk :
a. Hibah (Grant)
b. Pinjaman Lunak (Soft Loan)
c. Insentif Pajak

- Deposit-Refund

- Deposit-Recycling

- Environment Performance Bond

- Retribusi Pengguna (User Charge)

- Liability Insurance

- Retribusi Emisi (Emission Charge)

- Tradable Emission Permits

- Progressive Pricing

Langkah-langkah dalam implementasinya dan untuk dapat memanfaatkannya diperlukan sebagai berikut [3]:

- Pengambil keputusan harus mempunyai pengertian yang jelas tentang kondisi ekonomi yang berlaku dan kemampuan memahami kecenderungan ekonomi masa depan.

- Implementasi kegiatan insentif mensyaratkan adanya otoritas legal. Maka, penting bagi pengambil keputusan untuk memakai sistem hukum yang berlaku untuk menetapkan dimana dan bagaimana instrumen ekonomi dapat dimasukkan, atau mengembangkan sistem baru yang mengakomodasi pemanfaatan instrumen ekonomi. 


\section{Metode Penelitian}

Metode yang akan digunakan dalam penelitian ini adalah metode penelitian yuridis normatif, yakni penelitian yang mengacu pada norma-norma hukum yang terdapat dalam peraturan perundang-undangan. Selain itu digunakan metode penelitian kepustakaan, yaitu cara menghimpun data kepustakaan dengan melakukan studi dokumen [4]. Hal tersebut merupakan langkah awal pengumpulan data yang dilakukan diperpustakaan, serta artikel jurnal, makalah dan surat kabar.

Alat pengumpulan data yang dipergunakan peneliti yaitu studi kepustakaan, dengan data sekunder yang berupa bahan hukum primer, bahan hukum sekunder, dan bahan hukum tertier.

Alat pengumpul data dengan studi kepustakaan mencakup data sekunder yang berupa dokumen-dokumen, bukubuku dan bahan-bahan tertulis lainnya yang terkait dengan penelitian ini. Adapun jenis data sekunder yang digunakan dalam penelitian ini terdiri dari:

- Bahan hukum primer, yakni meliputi beberapa peraturan perundang- undangan antara lain Undang-Undang Nomor 7 Tahun 1992 tentang Perbankan, Undang-Undang Nomor 10 Tahun 1998 tentang Perubahan Atas Undang-Undang Nomor 7 Tahun 1992 tentang Perbankan, Undang-Undang Nomor 32 Tahun 2009 tentang Perlindungan dan Pengelolaan Lingkungan Hidup, Peraturan Pemerintah Nomor 27 Tahun 1999 tentang Analisis Mengenai Dampak Lingkungan, Peraturan Bank Indonesia Nomor 7/2/PBI/2005 tentang Penilaian Kualitas Aktiva Bank Umum, dan Surat Keputusan Direksi Bank Indonesia Nomor 27/162/KEP/DIR tentang Kewajiban Penyusunan dan Pelaksanaan Kebijaksanaan Perkreditan Bank Bagi Bank Umum;

- Bahan hukum sekunder yaitu buku-buku mengenai Hukum Perbankan, Hukum Lingkungan Hidup, Corporate Social Responsibility atau Tanggung Jawab Sosial dan Lingkungan Perusahaan, artikel-artikel jurnal, majalah, media elektronik lain dan juga buku-buku hukum lainnya;

- Selain itu juga digunakan bahan hukum tertier yaitu berupa kamus dan ensiklopedia dalam bidang hukum yang berkaitan dengan Perbankan.

Metode pengolahan analisa dan konstruksi data dilakukan secara kualitatif, yang artinya data yang diperoleh tersebut di atas akan dianalisis secara mendalam, holistif, dan komprehensif. Sifat pendekatan kualitatif terletak pada kumpulan informasi subyektif yang berasal dari penulis maupun sasaran penelitiannya. Hasil dari penelitian ini bersifat deskriptif-analitis karena memberikan gambaran sesuai dengan keadaan sebenarnya.

\section{Hasil dan Pembahasan}

Salah satu sektor yang mendukung meningkatnya perkembangan ekonomi tidak lepas dari adanya peran penting bank atau lembaga keuangan, dimana kehadiran lembaga-lembaga tersebut sesuai fungsinya telah menyalurkan dananya kepada setiap sektor usaha. Namun disadaribahwa peran bank tersebut di Indonesia sampai saat ini masih terbatas cara pandangnya, yaitu masih melihat pada aspek ekonomi semata (kelayakan ekonomi), belum melihat pada aspek yang lebih luas misalnya lingkungan hidup. Padahal dalam pelaksanaan kegiatannya baik sebagai entitas usaha maupun lembaga penyaluran kredit dari dana yang disalurkan dan digunakan oleh sektor usaha kepada pihak lain sering menimbulkan dampak luas terhadap lingkungan, antara lain: pencemaran lingkungan, penebangan hutan dan sebagainya.

Hasil pengamatan awal menunjukkan bahwa perbankan turut berperan dalam pencemaran dan perusakan lingkungan. Oleh karena itu sudah waktunya menerapkan instrumen insentif dan disinsentif dalam Kebijakan Pemberian Kredit Bank masing-masing dan pelaksanaannya terlebih dahulu dengan adanya pengaturan dari Otoritas Jasa Keuangan selaku lembaga yang mengawasi dan mengatur lembaga perbankan.

Berdasarkan Pasal 8 Undang-Undang No. 7 Tahun 1992 sebagaimana telah diubah dengan Undang-Undang No. 10 Tahun 1998 (selanjutnya disebut UU Perbankan) disebutkan bahwa dalam memberikan kredit atas pembiayaan berdasarkan prinsip syariah, Bank Umum wajib mempunyai keyakinan berdasarkan analisa yang mendalam atas itikad dan kemampuan serta kesanggupan nasabah debitur untuk melunasi utangnya atau mengembalikan pembiayaan dimaksud sesuai dengan yang diperjanjikan. Dalam hal ini pemberian kredit, bank dituntut agar dapat 
memperoleh keyakinan tentang kemampuan nasabah sebelum menyalurkan kreditnya, maka faktor melakukan penilaian secara cermat dan seksama terhadap watak, kemampuan, modal, agunan, dan prospekusaha debitur wajib menyakinkan bank. Undang-Undang Perbankan ini secara implisit menentukan bahwa pemberian kredit harus memiliki jaminan cukup menyandarkan diri pada keyakinan atau kemampuan dan kesanggupan dari debitur untuk melunasi hutangnya.

Untuk mendukung upaya tersebut pulalah, maka Bank Umum wajib memiliki Kebijaksanaan Perkreditan Bank (selanjutnya disebut "KPB") secara tertulis yang sekurang-kurangnya memuat semua aspek yang ditetapkan dalam Surat Keputusan Direksi Bank Indonesia No. 27/162/KEP/DIR tentang Kewajiban Penyusunan dan Pelaksanaan Kebijaksanaan Perkreditan Bagi Bank Umum (untuk selanjutnya disebut sebagai Pedoman Penyusunan Kebijaksanaan Perkreditan Bank, atau "PPKPB"). Surat Keputusan Direksi Bank Indonesia yang ditetapkan pada tanggal 31 Maret 1995 tersebut merupakan pedoman perkreditan yang dikeluarkan Bank Indonesia dan wajib dipenuhi oleh segenap Bank Umum di Indonesia. Alasan pengaturan pedoman perkreditan adalah karena:

- Bank melakukan kegiatan usaha terutama dengan menggunakan dana masyarakat yang dipercayakan kepada bank, sehingga kepentingan dan kepercayaan masyarakat wajib dilindungi dan dipelihara;

- Pemberian kredit merupakan kegiatan utama bank yang mengandung resiko yang dapat berpengaruh pada kesehatan dan kelangsungan usaha bank, sehingga dalam pelaksanaannya bank harus berdasarkan asas-asas perkreditan yang sehat;

- Demi terciptanya pemberian kredit yang konsisten yang didasarkan pada asas-asas perkreditan yang sehat yang dituangkan dalam suatu kebijaksanaan perkreditan bank yang tertulis.

Selain sebagai panduan dalam pelaksanaan semua kegiatan di bidang perkreditan, KPB juga bertujuan untuk mengoptimalkan pendapatan dan mengendalikan resiko Bank dengan cara menerapkan asas-asas perkreditan yang sehat secara konsekuan dan konsisten. Dengan demikian diharapkan Bank dapat terhindar dari resiko kegagalan pemberian kredit dan kemungkinan penyalahgunaan wewenang oleh pihak-pihak yang tidak bertanggung jawab dalam proses pemberian kredit.

Adapun KPB yang dimaksud sekurang-kurangnya memuat dan mengatur hal-hal pokok sebagai berikut:

- Prinsip kehati-hatian dalam perkreditan;

- Organisasi dan management perkreditan;

- Kebijaksanaan persetujuan kredit;

- Dokumentasi dan administrasi kredit;

- Pengawasan kredit;

- Penyelesaian kredit bermasalah.

Dalam KPB harus ditetapkan pokok-pokok pengaturan mengenai tata cara pemberian kredit yang sehat, pokokpokok pengaturan pemberian kepada pihak yang terkait dengan bank dan debitor-debitor tertentu, kredit yang mengandung resiko tinggi serta kredit yang perlu dihindari, sekurang-kurangnya mencakup:

- $\quad$ Pokok-pokok pengaturan mengenai:

a. Prosedur perkreditan yang sehat, termasuk prosedur persetujuan kredit;

b. Prosedur dokumentasi dan administrasi kredit serta prosedur pengawasan kredit;

c. Perlakuan terhadap kredit yang tunggakan bunganya dikapitalisasi (kredit yang diplafondering);

d. Prosedur penyelesaian kredit bermasalah dan prosedur penghapusbukuan kredit macet serta tata cara pelaporan kredit macet.

e. Tata cara penyelesaian barang agunan kredit yang telah dikuasai bank yang diperoleh dari hasil penyelesaian kredit.

- Pokok-pokok pengaturan mengenai pemberian kredit kepada pihak-pihak yang terkait dengan bank dan/atau debitor-debitor besar tertentu.

- Sektor ekonomi, segmen pasar, kegiatan usaha dan debitor yang mengandung resiko tinggi bagi bank. 
- Kredit yang perlu dihindari antara lain:

a. Kredit untuk tujuan spekulasi;

b. Kredit yang diberikan tanpa informasi keuangan yang cukup, dengan catatan bahwa informasi untuk kredit-kredit kecil dapat disesuaikan seperlunya oleh bank;

c. Kredit yang memerlukan keahlian khusus yang tidak dimiliki oleh bank;

d. Kredit kepada debitor bermasalah dan/atau macet pada bank lain.

Pihak-pihak bank yang terkait dalam kegiatan pemberian kredit adalah pejabat- pejabat bank dalam perkreditan seperti dewan komisaris, direksi, dan pejabat perkreditan lainnya dan.atau satuan-satuan kerja dalam organisasi bank. Selain itu bank diwajibkan untuk memiliki Komite Kebijaksanaan Perkreditan (KKP) dan Komite Kredit (KK). Dalam KPB wajib dicantumkan secara tegas dan jelas rincian fungsi, tugas, wewenang dan tanggung jawab para pihak yang terkait kegiatan pemberian kredit bank tersebut.

Dalam KPB Bank Umum setidaknya harus memuat pula kebijaksanaan persetujuan kredit minimal mencakup konsep hubungan total pemohon kredit, penetapan batas wewenang kredit, tanggung jawab pejabat pemutus kredit, proses persetujuan kredit, perjanjian kredit, dan persetujuan pencairan kredit.

Selanjutnya, Bank wajib memenuhi kelengkapan dokumen kredit, mengecek keabsahan dokumen kredit, dan melaksanakan penyimpanan dan penggunaan dokumentasi kredit yang baik dan tertib. Bank wajib melakukan pengawasan kredit yang mencakup pengawasan terhadap pejabat yang terkait dengan perkreditan, semua pihak yang berkaitan dengan bank dan debitor, serta wajib melakukan audit intern perkreditan yang merupakan upaya lanjutan dalam pengawasan kredit untuk memastikan bahwa pemberian kredit telah sesuai KPB dan telah mematuhi ketentuan yang berlaku dalam perjanjian kredit.

Sekalipun bank tidak mengharapkan terjadinya kredit bermasalah dan dengan penerapan KPB secara konsekuen dan konsisten diharapkan tidak timbul kredit bermasalah, namun seluruh pejabat bank yang terkait dengan perkreditan harus memiliki pandangan dan persepsi yang sama dalam mengantisipasi dan menangani terjadinya kredit bermasalah. Karenanya, bank wajib memiliki KPB yang memuat ketentuan dan kebijakan bank dalam hal terjadi kredit bermasalah.

Terdapat suatu ilustrasi mengenal keterkaitan dunia usaha dengan lingkungan hidup, yakni :

"Suatu badan usaha mendapatkan fasilitas kredit di Bank pelaksana,untuk ini Bank telah melakukan evaluasi yang mendalam tentangkarakternya, kemampuannya, modalnya, agunannya, dan kondisi sertaprospek usaha dan/atau kegiatan badan usaha yang bersangkutan"(Hasanuddin Rahman, 2000).

Dalam hubungan inilah salah satu perubahan dalam Undang Undang di sektor lingkungan terbaru yaitu UndangUndang No. 32 Tahun 2009 adalah menginternalisasi penggunaan instrumen ekonomi dalam perlindungan dan pengelolaan lingkungan hidup. Dengan demikian, peran Bank seharusnya dapat lebih ditingkatkan lagi dalam upaya berperan serta meningkatkan pengelolaan lingkungan hidup di Indonesia.

Dalam rangka pelaksanaan pembangunan nasional, Bank perlu terus ditingkatkan atau diperluas perannya, sehingga dapat memberikan manfaat optimal. Selama ini Bank belum melihat jauh kepada permasalahanpermasalahan dan akibat yang mungkin ditimbulkan oleh dunia usaha sehingga dengan timbulnya berbagai masalah yang terjadi seperti pencemaran lingkungan tersebut Bank merasa tidak ikut bertanggung jawab. Sebagai institusi keuangan yang memberikan pinjaman dananya kepada debitur, pada dasarnya Bank tersebut menghendaki agar pinjaman tersebut dapat dikembalikan sesuai dengan perjanjian yang disepakati, walaupun apabila dalam kegiatan yang dilakukan debitur menghadapi masalah dengan lingkungan, maka debitur akan menghadapi resiko. Apabila hal ini terjadi, maka debitur akan mengalami kerugian yang pada akhirnya menghadapi kesulitan untuk mengembalikan pinjamannya.

Seiring terjadinya kerugian yang dialami oleh debitur, maka Bank sebagai lender tentu akan menerima dampaknya pula, karena kredit yang diberikan menghadapi kemungkinan tidak akan dapat dikembalikan (macet). Untuk menghindari kerugian, maka sebenarnya Bank dapat meminta persyaratan-persyaratan di bidang lingkungan misalnya dengan melihat apakah AMDAL nya sudah ada, bagaimana environmental assessment dilakukan, apakah debitur sudah memiliki standar lingkungan. Bank juga perlu melakukan monitoring terhadap implementasi kegiatan 
yang dilakukan oleh debitur untuk melihat apakah dana yang digunakan tersebut telah sesuai dengan syarat-syarat lingkungan yang telah ditetapkan sebelumnya.

Permasalahannya adalah perbankan Indonesia umumnya masih enggan untuk memberi perhatian lebih besar terhadap permasalahan lingkungan. Hal itu terkait dengan paradigma lama yang menyebutkan bahwa bank sebagai entity business, dimaksudkan untuk mencetak laba setinggi-tingginya. Hal tersebut diperparah dengan persepsi bahwa peduli terhadap lingkungan hanya membebani perusahaan (just another cost).

Fenomena perbankan tersebut juga dialami oleh sebagian besar perusahaan di Indonesia. Menurut Rofikoh Rokhim [2] hanya sebagian kecil perusahaan di Indonesia yang menerapkan bisnis hijau dalam model bisnisnya, dan itupun belum optimal.

Implementasi atau best practices dari contoh Green Bank tersebut adalah cukup lengkap, baik secara internaleksternal, maupun yang terkait dengan bisnis-non bisnis. Namun demikian secara ringkas dapat disederhanakan menjadi sebagai berikut :

- Internal : menerapkan program efisiensi dan R3 (Reduce, Reused, Recycle) antara lain dengan mengoptimalkan daya inovasi dan kreativitas pegawai serta dengan memanfaatkan piranti teknologi.

- Eksternal : mengedukasi stake holders melalui program ramah lingkungan dan menawarkan eco-product pada pelanggan.

a. Corporate Social Responsibility (CSR) : melakukan kegiatan dalam rangka meningkatkan kualitas lingkungan dan pemberdayaan masyarakat atau terlibat dalam sosialisasi green business.

b. Kredit : penyaluran kredit pada sektor atau industri ramah lingkungan seperti energi terbarukan (renewable energy), produk organik, industry kreatif yang memanfaatkan limbah, produk efisien (high end product), pengolah limbah, serta pertanian dan kehutanan, memberikan insentif bunga kepada debitur yang memiliki bisnis model yangramah lingkungan, menerapkan prinsip sustainability dalam analisakelayakan kredit debitur secara bertahap sebagai bagian klausul kreditserta dipercaya menjadi bank penyalur kredit two steps loan darilembaga - lembaga dunia untuk proyek lingkungan.

c. Dana : menyediakan produk giro, tabungan atau deposito yangberafiliasi dengan rekening komunitas lingkungan.

\section{Kesimpulan}

Hasil pengamatan dan evaluasi secara rasional mengenai penerapan instrumen ekonomi lingkungan hidup dalam kebijakan pemberian kredit perbankan pada prinsipnya sangat diperlukan, karena peranan perbankan yang memberikan kredit/pembiayaan terhadap usaha dan/atau kegiatan nasabah tentunya berdampak pada lingkungan. Pencegahan masalah lingkungan hidup seperti pencemaran dan perusakan lingkungan dapat dimulai dari pemberian kredit oleh perbankan dengan menerapkan instrumenekonomi lingkungan hidup yang salah satunya adalah insentif dan disinsentif.

\section{Referensi}

[1] Hasanuddin Rahman, Kebijakan Kredit Perbankan Yang Berwawasan Lingkungan, Cet.1, (Bandung: PT Citra Aditya Bakti, 2000).

[2] Rofikoh Rokhim, Green Business : Strategi Pembangunan Berkelanjutan Bagi Perusahaan. Makalah Seminar Nasional Green Business; A Global New Deal, A Shifting of Economics Paradigm, Jakarta, 2010.

[3] Surna Tjahja Djajadiningrat dkk., Green Economy (Ekonomi Hijau), Edisi Revisi (Bandung: Rekayasa Sains, 2014).

[4] Soerjono Soekanto. Pengantar Penelitian Hukum (Jakarta: UI Press, 1986).

[5] Takdir Rahmadi. Hukum Lingkungan di Indonesia (Jakarta: Rajawali Pers, 2016). 